\title{
Pasteuria penetrans (Bacilli: Bacillales: Pasteuriaceae) ${ }^{1}$
}

\author{
Ruhiyyih Dyrdahl-Young and Peter DiGennaro²
}

\section{Introduction}

Biological control agents of plant-parasitic nematodes are typically very specific natural enemies of the target plant pest nematodes. When commercialized, growers can use these natural agents in the soil around their crop plants to limit the damage caused by harmful plant-parasitic nematodes. One of the best studied biological controls of nematodes is a bacterium in the genus Pasteuria (Figure 1). Pasteuria penetrans is an obligate parasite of root-knot nematodes (Meloidogyne spp.). Pasteuria penetrans is an endospore-forming bacterium that persists in the soil until a suitable nematode host encounters the spore. The Pasteuria spores adhere to the nematode cuticle (outer surface), infect the nematode, and develop inside of the nematode body.

The growth of Pasteuria spp. inhibits the nematode from producing eggs. It is this disruption of nematode fertility that makes Pasteuria spp. such a promising biological control agent for root-knot nematode. Another species of Pasteuria (Pasteuria nishizawae) infects Heterodera glycines (soybean cyst nematode) and is commercially available for growers in the Americas and Europe. One EPA report states that Pasteuria species are present in 80 countries on at least five continents (2012). Traditionally, a new isolate of bacteria was named when it could be cultured in a lab. However, with modern genomic technology, taxonomic characterization of unique bacterial isolates allows for the identification of different Pasteuria spp. without the need for cultures. This is important as Pasteuria is an obligate parasite and therefore cannot be grown outside of its host using traditional bacteria culturing techniques. This has previously limited the ability to identify and characterize more Pasteuria spp. despite this bacteria's wide distribution.

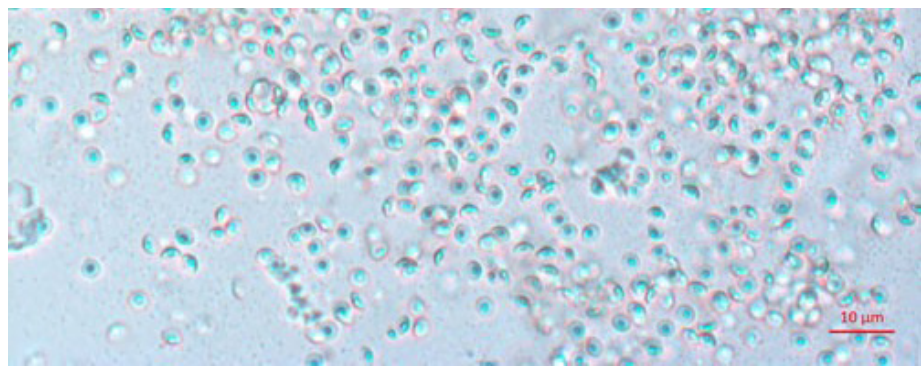

Figure 1. Endospores of Pasteuria penetrans.

Credits: Weiming Hu, UF/IFAS

\section{Distribution}

Distinct species of Pasteuria associate with different genera of nematodes have been identified world-wide. For every plant-parasitic nematode there is potentially a specific and adapted isolate of Pasteuria. Root-knot nematodes have a very wide host range which includes most economically important crops produced world-wide. Pasteuria penetrans has been reported from, North America (Noel 1994), India (Mohan 2012), Senegal (Bekal et al. 2001), the United Kingdom (Davies et al. 2011) and Iraq (Fattah et al. 1989). There are likely many more isolates of Pasteuria spp. in more locations that are yet to be characterized.

1. This document is EENY-718, one of a series of the Department of Entomology and Nematology, UF/IFAS Extension. Original publication date September 2018. Visit the EDIS website at https://edis.ifas.ufl.edu for the currently supported version of this publication. This document is also available on the Featured Creatures website at http://entomology.ifas.ufl.edu/creatures.

2. Ruhiyyih Dyrdahl-Young; and Peter DiGennaro, Department of Entomology and Nematology; UF/IFAS Extension, Gainesville, FL 32611.

The Institute of Food and Agricultural Sciences (IFAS) is an Equal Opportunity Institution authorized to provide research, educational information and other services only to individuals and institutions that function with non-discrimination with respect to race, creed, color, religion, age, disability, sex, sexual orientation, marital status, national origin, political opinions or affiliations. For more information on obtaining other UF/IFAS Extension publications, contact your county's UF/IFAS Extension office. 


\section{Description}

Pasteuria spp. are most recognizable as the mature endospore form (Figure 1). This life stage of the bacteria is used to establish ultrastructure (measurements of key features using high resolution microscopic images) and novel characteristics unique to each species of Pasteuria spp. Endospores of Pasteuria penetrans are about $3 \mu \mathrm{m}$ in diameter and $1.8 \mu \mathrm{m}$ in height (Chen et al. 1997). The endospores are visible as they stick to the cuticle (outer surface) of the nematode (Figure 2). As the nematode starts to feed on plant root tissues, the endospores penetrate the nematode cuticle, germinate and form microcolonies within the nematode's body. These microcolonies vary in size but are popcorn shaped and eventually mature into thalli, sporogonium, and finally mature endospores which are dispersed into the soil, ready to infect other root-knot nematodes.

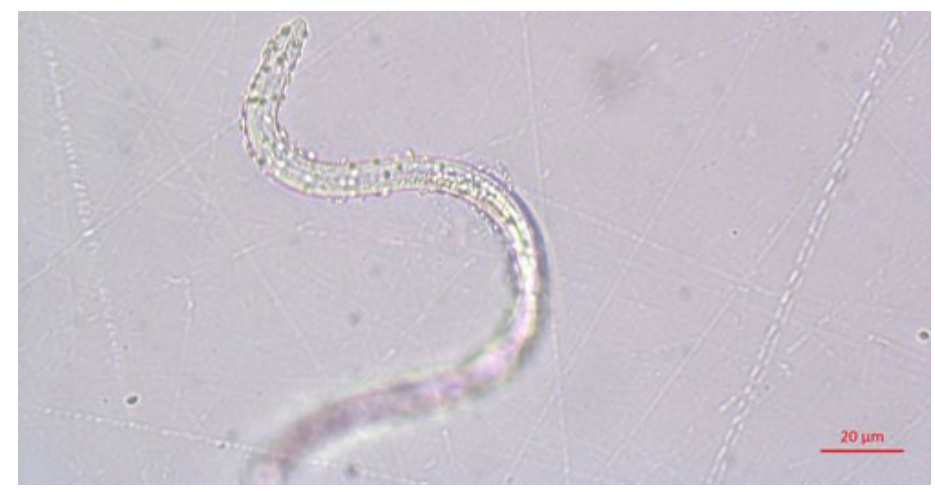

Figure 2. Meloidogyne arenaria nematode with Pasteuria penetrans endospores adhering to its cuticle.

Credits: Ruhiyyih Dyrdahl-Young, UF/IFAS

\section{Life Cycle and Biology}

Pasteuria endospores persist in the soil until a suitable host nematode comes into physical contact with the bacterium. Once the nematode begins to feed on the root tissue, the endospore germinates and grows in the body of the infected nematode. The infection process starts when a Pasteuria endospore adheres to the cuticle (outside covering) of the nematode (Figure 2). Next, after the nematode penetrates a host plant's roots and feeds on inner root tissues, the endospore develops a germination tube. This tube pierces through the cuticle of the nematode and begins to form mycelial-like (popcorn-shaped) balls in the ovarian tissue of the nematode. These mycelial-like balls (Figure 3) are the first of several structures that Pasteuria forms during sporulation.

As the bacterium develops, the mycelial-like balls mature into thalli (Figure 4), sporogonium (Figure 5), and eventually more mature endospores (Figure 6). The ovarian tissue and body of the nematode fills with endospores which replace nematode eggs (Figure 7). A healthy root-knot nematode can lay up to as many as 1,000 eggs in the soil. A root-knot nematode infected with Pasteuria penetrans does not lay any viable eggs. This could cause the nematode population to decrease dramatically in a field with high populations of Pasteuria endospores and benefit the current crop as well as future plantings through population suppression.

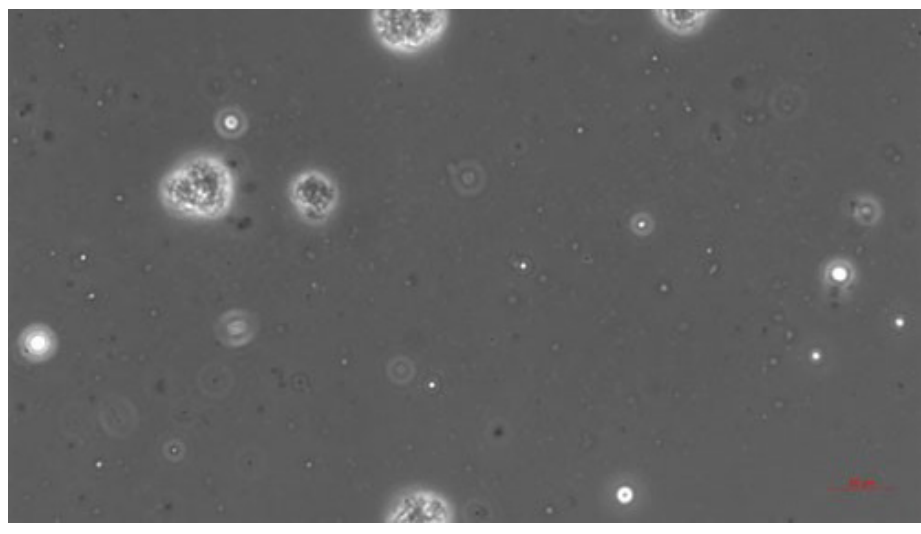

Figure 3. Mycelial-like structures of Pasteuria penetrans, image taken from the body contents of an infected Meloidogyne arenaria nematode. Image taken 15 days after exposure to Pasteuria penetrans. Credits: Ruhiyyih Dyrdahl-Young, UF/IFAS

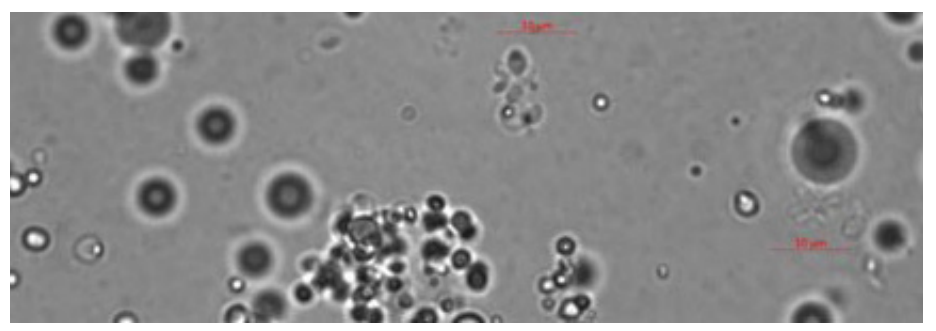

Figure 4. Thalli structure of Pasteuria penetrans taken from inside an infected root-knot nematode, 20 days after exposure to endospores. Credits: Ruhiyyih Dyrdahl-Young, UF/IFAS

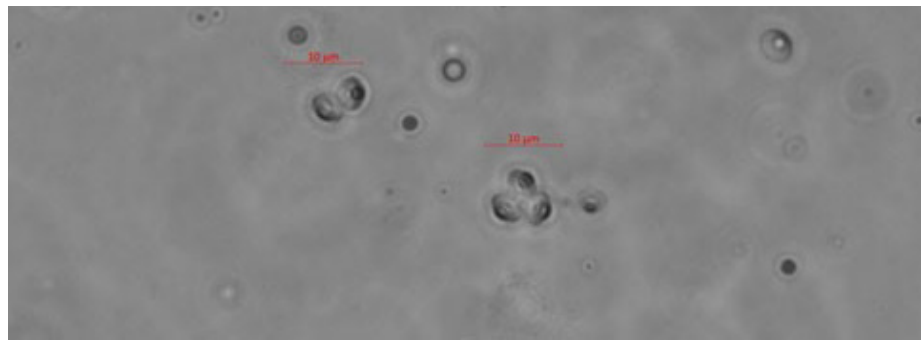

Figure 5. Sporogonium of Pasteuria penetrans taken 30 days after rootknot nematode exposure to Pasteuria penetrans endospores. Credits: Ruhiyyih Dyrdahl-Young, UF/IFAS

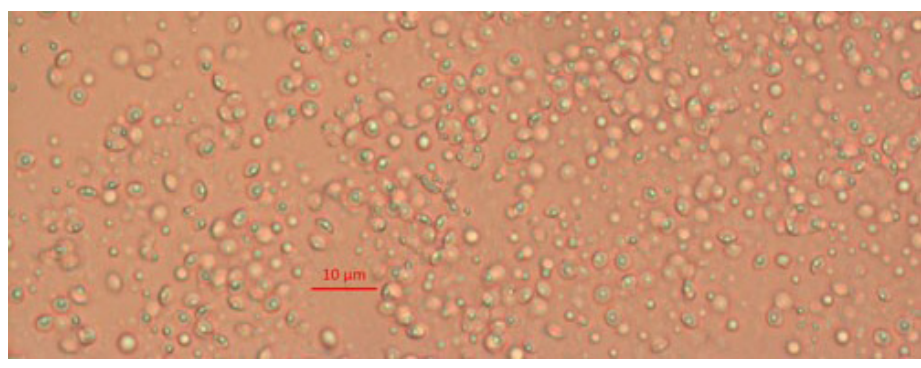

Figure 6. Mature Pasteuria endospores.

Credits: Weiming Hu, UF/IFAS 


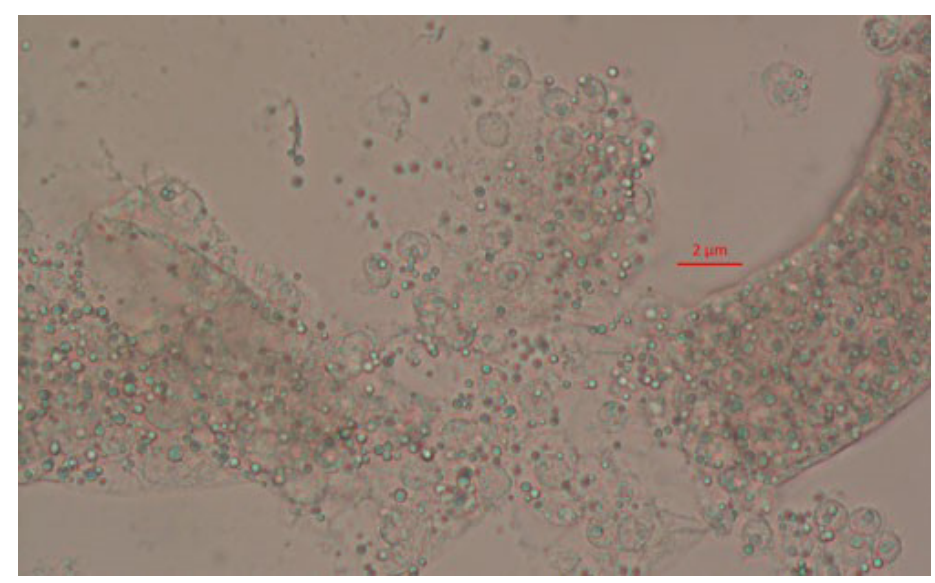

Figure 7. Pasteuria penetrans infected ovarian tissue of Meloidogyne arenaria. Image taken 30 days after exposure to Pasteuria penetrans. Credits: Ruhiyyih Dyrdahl-Young, UF/IFAS

\section{Hosts}

Pasteuria has a specific and limited host range which does not include humans, or other soil organisms (like insects, mites and earth worms). There are five species of Pasteuria that infect plant-parasitic nematodes. They are most easily distinguished from one another by their host range. These include: Pasteuria thorneii that infect Pratylenchus spp. (lesion nematode) (Starr and Sayre 1988), 'Candidatus Pasteuria usgae' a parasite of Belonolaimus spp. (sting nematode) (Giblin-Davis 2003), Pasteuria nishizawae that is a parasite of Heterodera glycines (soybean cyst nematode) (Atibalentja et al. 2004), Pasteuria hartismeri parasitic to Meloidogyne ardenensis (root-knot nematode), and Pasteuria penetrans that attacks Meloidogyne spp. (root-knot nematode) (Bishop et al. 2007).

\section{Economic Importance}

The economic impacts of Pasteuria penetrans are difficult to estimate, as there are no commercial products containing these endospores. At the time of publication, there is one commercially available Pasteuria-based nematode control. This product contains Pasteuria nishizawae endospores in a soybean seed coat. According to the manufacturer, the Pasteuria nishizawae seed coat can increase yields 2.7 bushels per acre higher (and as much as 10 bushels/acre) than seeds coated with insecticide/fungicide alone (Syngenta). In June 2018, the soybean price per bushel was $\$ 9.55$ and the average yield in Florida was 60 bushels/acre. In Florida in 2018 there were 14,000 acres of soybeans harvested. At the current price of soybeans, a yield increase of 2.7 to 10 bushels/acre would translate into a $\$ 361,000$ to $\$ 1.3$ million increase in profits in Florida. Root-knot nematodes are one of the world's most devastating plant-parasites. The rootknot nematode Meloidogyne incognita, has a host range that is estimated to include over 2,000 plants including virtually all economically important Florida crops. One conservative estimate of global crop loss caused by root-knot nematode is 5\% (Sasser and Sarter 1985). Pasteuria penetrans would potentially have a great economic impact if successfully deployed as a biological control agent.

\section{Management}

At present, management recommendations of root-knot nematodes using Pasteuria penetrans are premature. There are studies in micro-plots that suggest adding Pasteuria penetrans endospores (at a rate of $100,000 / g$ soil) will suppress the growth of root-knot nematode populations. In one Florida field where a continuous peanut crop was established, the Pasteuria penetrans endospores significantly reduced the population of infective juvenile root-knot nematodes (Chen et al. 1996).

\section{Selected References}

Atibalentja N, Jakstys BP, Noel GR. 2004. "Life cycle, ultrastructure, and host specificity of the North American isolate of Pasteuria that parasitizes the soybean cyst nematode, Heterodera glycines." Journal of Nematology 36(2): 171-180.

Bekal S, Borneman J, Springer J, Giblin-Davis RM, Becker JO. 2001. "Phenotypic and molecular analysis of a Pasteuria strain parasitic to the sting nematode." Journal of Nematology 33(2-3): 110-115.

Bishop A H, Gowen SR, Pembroke B, Trotter JR. 2007. "Morphological and molecular characteristics of a new species of Pasteuria parasitic on Meloidogyne ardenensis." Invertebrate Pathology 96: 23-33.

Chen ZX, Dickson DW, Freitas LG, Preston JF. 1997. "Ultrastructure, morphology, and sporogenesis of Pasteuria penetrans." Phytopathology 87(3): 273-283.

Chen ZX, Dickson DW, McSorley R, Mitchell DJ, Hewlett TE. 1996. "Suppression of Meloidogyne arenaria Race 1 by soil application of endospores of Pasteuria penetrans." Journal of Nematology 28(2): 159-168.

Davies KG, Rowe J, Lopez RM, Opperman CH. 2011. "Re-evaluation of the life-cycle of the nematode-parasitic bacterium Pasteuria penetrans in root-knot nematodes, Meloidogyne spp." Journal of Nematology 13(7): 825-835.

Environmental Protection Agency (EPA) (February 2012). Pasteuria nishizawae - Pn1 (016455) Fact Sheet. https:// www3.epa.gov/pesticides/chem_search/reg_actions/registration/fs_PC-016455_28-Feb-12.pdf. (12 September 2018) 
Fattah FA, Saleh HM, Aboud HM. 1989. "Parasitism of the citrus nematode, Tylenchulus semipenetrans, by Pasteuria penetrans in Iraq." Journal of Nematology 21(3): 431-433.

Giblin-Davis RM. 2003. 'Candidatus Pasteuria usgae' sp. nov., an obligate endoparasite of the phytoparasitic nematode Belonolaimus longicaudatus." International Journal of Systematic and Evolutionary Microbiology 53(1): 197-200.

Mohan S, Mauchline TH, Rowe J, Hirsch PR, Davies KG. 2012. "Heterodera cajani (Nematoda: Heteroderidae) exhibit inverted attachment and altered germination in cross-infection studies with Globodera pallida (Nematoda: Heteroderidae)." FEMS Microbiology Ecology 79(3):

675-684.

Noel GR, Stanger BA. 1994. "First report of Pasteuria sp. attacking Heterodera glycines in North America." Journal of Nematology 26(4): 612-615.

Sasser JN, Sarter CC. 1985. View of the International Meloidogyne Project 1975â€"1984. In Advanced Treatise on Meloidogyne. Raleigh pp. 19-24.

Starr MP, Sayre RM. 1988. "Pasteuria thorneii sp. nov. and Pasteuria penetrans sensu stricto emend., mycelial and endospore-forming bacteria parasitic, respectively, on plant-parasitic nematodes of the genera Pratylenchus and Meloidogyne." Annales de Institute Pasteur Microbiologie 139(1): 11-31.

Syngenta United States. (2018). Clariva ${ }^{\oplus}$ Elite Beans. http:// www.syngenta-us.com/seed-treatment/clariva-elite-beans. (10 September 2018) 